\title{
Elderly individuals in multigenerational households: Family composition, satisfaction with life and social involvement
}

\section{Longevos em domicílios multigeracionais: condições \\ sociodemográficas, humor, funcionalidade, envolvimento social e satisfação com a vida}

\author{
Maria Clara Gonçalves Monteiro de OLIVEIRA $^{1}$ iD 0000-0003-0374-2213 \\ Henrique SALMAZO-SILVA2 ID) 0000-0002-3888-4214 \\ Lucy GOMES² ID 0000-0002-6673-5507 \\ Clayton Franco MORAES ${ }^{2}$ iD 0000-0003-2605-1335 \\ Vicente Paulo ALVES ${ }^{2}$ iD 0000-0002-1412-830X
}

\begin{abstract}
The purpose of this study was to investigate the link between multi-generational household arrangements (uni-, bi- or tri-generational) and sociodemographic variables, functional performance, mood, social support and life satisfaction in cognitively healthy elderly individuals. This is a cross-sectional, descriptive and quantitative study. A total of 107 elderly individuals from the Federal District were evaluated using the Geriatric Depression Scale, the Mini Exame do Estado Mental (Mini-Mental State Examination), the Scales of Basic, Instrumental and Advanced Activities of Daily Living, the Perceived Social Support, and the Life Satisfaction Scale. Bivariate statistical analysis indicated that tri-generational arrangements were associated with being female, being a widowed individual and having more children; and uni- or bi-generational arrangements were associated with a greater life satisfaction in comparison to people of the same age, a bigger participation in cultural activities and driving an automobile. These findings indicate that, for elderly individuals, living arrangements are associated with family composition, life satisfaction and social engagement.
\end{abstract}

Keywords: Depression; Elderly; Housing; Social participation; Social support.

1 Universidade Católica de Brasília, Escola de Saúde e Medicina, Curso de Graduação em Psicologia. Brasília, DF, Brasil.

2 Universidade Católica de Brasília, Escola de Saúde e Medicina, Pós-Graduação em Gerontologia. Quadra 7, Lote 01, Águas Claras, 71966-700, Brasília, DF, Brasil. Correspondence to: H. SALMAZO-SILVA. E-mail: <henriquesalmazo@yahoo.com.br>.

Support: Conselho Nacional de Desenvolvimento Científico e Tecnológico, linked to the "Padrões de envelhecimento físico cognitivo e psicossocial em idosos longevos que vivem em diferentes contextos" project.

$\boldsymbol{\nabla} \boldsymbol{\nabla} \boldsymbol{v}$

How to cite this article

Oliveira, M. C. G. M., Salmazo-Silva, H., Gomes, L., Moraes, C. F., \& Alves, V. P. (2020). Elderly individuals in multigenerational households: Family composition, satisfaction with life and social involvement. Estudos de Psicologia (Campinas), 37, e180081. http:// dx.doi.org/10.1590/1982-0275202037e180081 


\section{Resumo}

O objetivo deste estudo foi investigar a associação entre os arranjos domiciliares multigeracionais (uni, bi ou trigeracionais) e variáveis sociodemográficas, desempenho funcional, humor, suporte social e satisfação com a vida em idosos longevos cognitivamente saudáveis. Trata-se de estudo transversal, descritivo e quantitativo. Foram avaliados 107 idosos do Distrito Federal, por meio dos seguintes instrumentos: Geriatric Deepression Scale, Mini Exame do Estado Mental, Escala de Atividades Básicas, Instrumentais e Avançadas de Vida Diária, Escala de Suporte Social Percebido e de Satisfação com a Vida. Análises estatísticas bivariadas indicaram que arranjos trigeracionais associaram-se ao sexo feminino, ao estado de viuvez e à existência de mais filhos; já os arranjos uni ou bigeracionais associaram-se à maior satisfação com a vida em comparação com pessoas da mesma idade, bem como à maior participação em atividades culturais e à prática de dirigir automóvel. Esses achados indicam que, para longevos, os arranjos domiciliares associam-se a variáveis de composição familiar, satisfação com a vida e envolvimento social.

Palavras-chave: Depressão; Idoso; Domicílio; Participação social; Apoio social.

With an aging population, the needs of the elderly (people who are more than 80 years-old) have become an increasing concern for managers, professionals and academics in offering care possibilities, so that aging is a well-assisted process. The family can become a social support system, providing functional, economic, social and emotional assistance to the elderly, as well as providing support to other family members (Paúl, 2005; Rabelo \& Neri, 2015). The arrangements of these houses can be the most diverse, from living alone or with the spouse to living with other descendants as well, setting up an intergenerational household arrangement (Borges \& Magalhães, 2011) with these members, whether being passive or active in providing or receiving any type of social support. In addition to protection, the household arrangement provides opportunities to preserve functional performance in old age. However, living with different generations can become a stress factor for elderly individuals (Paúl, 2005).

Regarding social support, there are plenty of studies in the field of gerontology about how roles and social relations influence the life of elderly individuals (Neri \& Vieira, 2013; Paúl, 2005; D’Orsi, Xavier, \& Ramos, 2011; Teerawichitchainan, Pothisiri, \& Long, 2015), whether this individual is in the receiving or giving end of this support. In the context of care of elderly individuals, the household arrangement becomes a topic for debate, for different reasons: (a) the support received, whether it is instrumental, emotional or financial, can compensate for the losses associated with the aging process and be a source of health and well-being (D'Orsi et al., 2011); (b) the agents that make up the household arrangement can be of the most diverse type, such as children, grandchildren, great-grandchildren, spouses and other members of a larger family, and because of this variability, the role of support can be modified according to the types of relationship established and their meanings: reciprocity, obligation, gratitude, and conflicts between the individual's giving and receiving standards (Teerawichitchainan et al., 2015); c) for the advanced elderly, family action and intergenerational relations may be influenced by sociodemographic, mood and health characteristics, as already observed in Brazilian studies (Rabelo \& Neri, 2015; Rosa, Benício, Alves, \& Lebrão, 2007). Intergenerational cohabitation and an increasing number of elderly household heads can generate supporting actions as well as intergenerational conflicts, but at the same time may evoke role conflicts, cultural shocks, and intergenerational relationship issues (Kenne \& Batson, 2010).

Among the main types of support offered to the elderly is the instrumental support, directed to the accomplishment of the Basic, Instrumental and Advanced Activities of Daily Living (D'Orsi et al., 2011; Neri \& Vieira, 2013). Among them we have the Basic Activities of Daily Living (BADL), Instrumental Activities of Daily Living (IADL) or the Advanced Activities of Daily Living (AADL). The BADL are basic personal activities such as bathing, dressing alone, eating without help from others, etc. (D'Orsi et al., 2011); Both the IADL and the AADL are instrumental activities performed in the community and require a preserved physical and cognitive functionality (Neri \& Vieira, 2013), such as going to the supermarket, using a kitchen, using public transportation and scheduling medical appointments (D'Orsi et al., 2011). 
According to Neri and Vieira (2013), the AADL places the elderly in an active position in their communities, developing actions at work, with the family and in other social institutions. The level of functionality can be verified by the level of dependence the elderly individual has to perform these tasks. The lower the dependency on third-parties, the more the elderly's functionality and autonomy will be preserved for the performance of tasks (D'Orsi et al., 2011). The correlations between the degree of dependence and the age of the participants show that the greater the age, the greater the dependence caused by functional loss, which is confirmed by the results of the studies from D'Orsi et al. (2011) and Neri and Vieira (2013) on octogenarian elderly individuals.

Therefore, actions of social support may attenuate the stress associated with functional limitations (Paúl, 2005). In the family arrangement, the bonds are involuntary (Paúl, 2005), and the feeling of obligatoriness towards the care that elderly individuals require may be a predictor of stress for both families and elderly individuals. In addition, the loss of functionalities can be attributed to an "excessive care", preventing elderly individuals from performing their own activities and depriving them of making their own decisions (D'Orsi et al., 2011; Neri \& Vieira, 2013; Paúl, 2005).

Seeking to understand how the home arrangement and the family role undertook by the elderly influence in their mood and in the preservation of their own functionality can provide understanding about the health conditions of the individual. The nature of relationships which are closer to the social life of the elderly can benefit both, as well as it can impair their health and perception of life (Fuller-Iglesias, Webster, \& Antonucci, 2015). The most common household arrangement among the elderly population is living with other family members, and it is also common a greater number of illnesses, cognitive decline and greater mood changes (Rabelo \& Neri, 2015). The need to have more studies that investigate the impacts of the relationship between family environment and health conditions justifies the production of this study.

\section{Method}

The present study is a quantitative, descriptive and cross-sectional study based on the project "As alterações da longevidade relacionadas a idosos octogenários do Distrito Federal na abordagem interdisciplinar" (Changes in longevity related to octogenarians of the Federal District (Brazil) in a interdisciplinary approach) database, approved by the Ethics Research Committee, registered in the Certificate of Presentation for Ethical Appreciation (CPEA) number 50075215.2.0000.0029, linked to the Postgraduate Program in Gerontology of the Universidade Católica de Brasilia (UCB, Catholic University of Brasília).

\section{Participants}

The participants in this study are octogenarian elderly individuals, evaluated between 2016 and 2017 . The sample was obtained by convenience and recruited at the outpatient care clinic of the Cardiology Institute of the Federal District (Distrito Federal, Brazil). When selected, the elderly and their families were informed about the objectives of this study, oriented in order to ensure its confidentiality and anonymity, and instructed in order to clarify their free and spontaneous participation in the study by signing the Informed Consent Term. After consenting, the elderly individuals were investigated in three places, namely: the University Hospital of the Universidade Católica de Brasilia (UCB, Catholic University of Brasília), the Cardiology Institute of the Federal District; the Laboratório de Avaliação Física e Treinamento (LAFIT, Laboratory of Physical Evaluation

and Training); and the SABIN Laboratory for clinical analysis. In each site, a type of evaluation was developed, having the cognitive, medical and health status evaluation performed at the Instituto do Coração do Distrito Federal (ICDF, Heart Institute of the Federal District) by undergraduate and graduate UCB students; the physical 
and functional evaluations were made in the LAFIT by undergraduate physiotherapy and physical education students, and by postgraduate Gerontology students; the collection of blood samples was performed by the SABIN Laboratory.

In this study, 107 elderly people were selected from a population of 221 advanced elderly individuals. Inclusion criteria were: being more than 78 years-old, residing in the Federal District or nearby, consenting to participate in the study, and being available for social, physical and laboratory evaluations. The following subjects were excluded: bedridden elderly individuals, wheelchair users, individuals with severe hearing loss, uncontrolled psychiatric morbidity, and individuals with cognitive decline in the Mental State Mini Examination (MSME) (Brucki, Nitrini, Caramelli, Bertolucci, \& Okamoto, 2003): a score less than 17 points for illiterate individuals, 22 points for the elderly who had between 1 and 4 years of education; 24 points for individuals who had between 5 and 8 years of education; and 26 points for the elderly who had 9 years or more of education (FIBRA Study criteria) (Neri et al., 2013).

When adopting this exclusion criterion, it was observed that the pattern of elderly people who reported residing in tri-generational households tended to be composed of elderly individuals with MSME cognitive decline $(p=0.061)$, indicating that this home arrangement may be a possible alternative care facing the individual's cognitive limitations. Thus, the authors decided to investigate only cognitively healthy individuals, and also because the present study investigates the association between subjective variables and the household arrangement.

\section{Instruments}

The instruments used in the data collection were: questionnaires with sociodemographic information, and instruments of global cognitive evaluation (mood, social support, life satisfaction) and performance in basic, instrumental and advanced activities of Daily Living.

The household arrangement was the dependent variable and classified into three categories: individuals who lived alone; who lived in uni- or bi-generational arrangement, including the elderly who reported living with their spouses and/or children; and individuals who lived in tri-generational arrangements, accompanied by three different generations, which could include spouses, children and grandchildren. Almost all three-generational arrangements were necessarily composed of three generations, with the exception of four cases, in which the elderly reported living only with their grandchildren.

The other sociodemographic variables evaluated were: age - quantified in years; education - quantified in years of formal education; sex - male or female; marital status - unmarried, widowed, married, divorced; and perceived income sufficiency for the needs of daily life - answered as "yes" or "no".

The global cognitive assessment was measured by the Mental State Mini Examination, composed of 30 questions with scores ranging from 0 to 30, with questions that evaluate orientation in time and space, episodic memory, immediate repetition, cognitive praxis, visuospatial and language functions (Brucki et al., 2003).

Mood was evaluated using the Geriatric Depression Scale (GDS), which is a 15-item instrument whose scores range from 0 to 15 points, adapted to the Brazilian population by O.P. Almeida and Almeida (1999), based on the original scale created by Yesavage et al. (1983) with 30 items. The objective of the GDS was to detect the presence of suggestive symptoms of depression in elderly individuals, with a cut-off point of 6 points.

The perceived social support was evaluated by an instrument with five scalar questions constructed

4 from the Interpersonal Support Evaluation List (ISEL) (Cohen, Mermelstein, Kamarck, \& Hoberman, 1995; 
Neri \& Vieira, 2013). These questions were: "would you say you have several people to talk to when you feel alone? "; "Would you say you meet and talk to friends and family?"; "Would you say you would easily find someone who can help you in your daily tasks if you were sick?"; "Do you have anyone who you can count on when you need an advice on how to deal with a problem?"; "Do you have at least one person whose opinion you fully trust?". Response options were encoded in the Likert Scale from 1 to 4, including: "never", "sometimes", "most often", and "always". The scale items measure the availability of socio-emotional, instrumental, informative and affective support, and in this study, the score of each item was analyzed.

Life satisfaction was evaluated through a questionnaire containing an item about satisfaction with life as a whole, an item about satisfaction comparing the other individuals of the same age, six items about satisfaction, relating to memory domains; functional and problem-solving capacity, friends and family relations, environment, access to health services and means of transportation (Neri, 2002). Each item was composed of a scale from 0 to 3 points, whose sum ranged from 1 to 24. In this study each item was investigated separately (mean score of 0 to 3 points) and also their sum. Older people who scored < 21 were considered to have less satisfaction with life and those who scored $>22$ were considered as individuals with greater life satisfaction.

Functional performance variables included: Functional Performance - absence or presence of difficulties in the Basic Activities of Daily Living (BADLs), related to self-care (toileting, eating, moving, commuting, bathing, doing personal hygiene); and in the Instrumental Activities of Daily Living (IADLs), such as: cooking, using means of transportation, using the telephone, shopping; and Advanced Activities of Daily Living (AADLs) - visiting people; receiving guests; going to church, to social meetings; attending cultural events; driving an automobile; making short trips; making long, distant trips; carrying out voluntary work; carrying out paid work activities; participating in boards of directors; attending university and going to elderly-focused social groups. IADLs are related to the maintenance of an independent life and the AADLs are related to the engagement in recreational, social, occupational and leisure activities (Lawton \& Brody 1969; Reuben, Laliberti, Hiris, \& Mor, 1990). Elderly individuals with BADL or IADL limitations were classified as being individuals "with limitations" and the elderly individuals with no limitation were classified as being "independent". In the AADLs, each activity was analyzed separately, and the elderly person was classified as "an individual who participates" - those who reported doing things, and those who were classified as "individuals who do not participate" for those who answered questions with "have never done it" or "stopped doing it".

\section{Data analysis}

The data were analyzed quantitatively through non-parametric comparisons of means (Kruskal-wallis) or percentages (Chi Square) between groups, in order to identify the association between living arrangements and sociodemographic variables, mood, social support, functional performance and life satisfaction. The significance level of the analyzes will be $p<0.05$.

\section{Results}

Of the 107 advanced elderly individuals selected, 22 of them lived alone, 50 in uni- or bi-generational households, and 35 in tri-generational households. The analyzes indicated that there was a higher prevalence of women, widowed individuals, and a higher number of children for elderly individuals living in tri-generational arrangements. Elderly individuals living in uni- or bi-generational environments were mostly males (54\%) and married. For elderly individuals who reported living alone, there was a higher prevalence of widowed 
individuals, followed by unmarried individuals. No statistically significant associations were found between the household arrangement, age, education, mood, mean MSME score, and the individual presenting any BADL and IADL difficulties (Table 1).

Regarding the other variables, elderly individuals who lived in uni- or bi-generational households indicated that they were more satisfied with life compared to the same age group, and reported the highest prevalence of participation in the "cultural activities" and "driving an automobile" AADLs. On the other hand, no differences were observed in the other domains of life satisfaction. With regard to the perceived social support, no difference between groups was reported. However, there was a tendency of the group with uni- or bi-generational arrangements to have a greater availability of social-emotional support when compared to elderly individuals who reported living alone or in tri-generational environments (Table 2,3,4).

\section{Discussion}

The results of this study indicate that the household arrangements for advanced elderly individuals are associated with the family composition, variables of life satisfaction and social involvement. It was observed that elderly individuals with tri-generational arrangements were female, widowed and with a larger number of children. The engagement in these activities may be related to motivational and relational factors, since participation in social activities may increase the perception of the elderly individual's quality of life (Borges \& Magalhães, 2011; Mantovani, Lucca, \& Neri, 2016; Cachioni et al., 2017).

Table 1

Elderly individuals' household arrangement and sociodemographic variables. Distrito Federal (Brazil), 2018

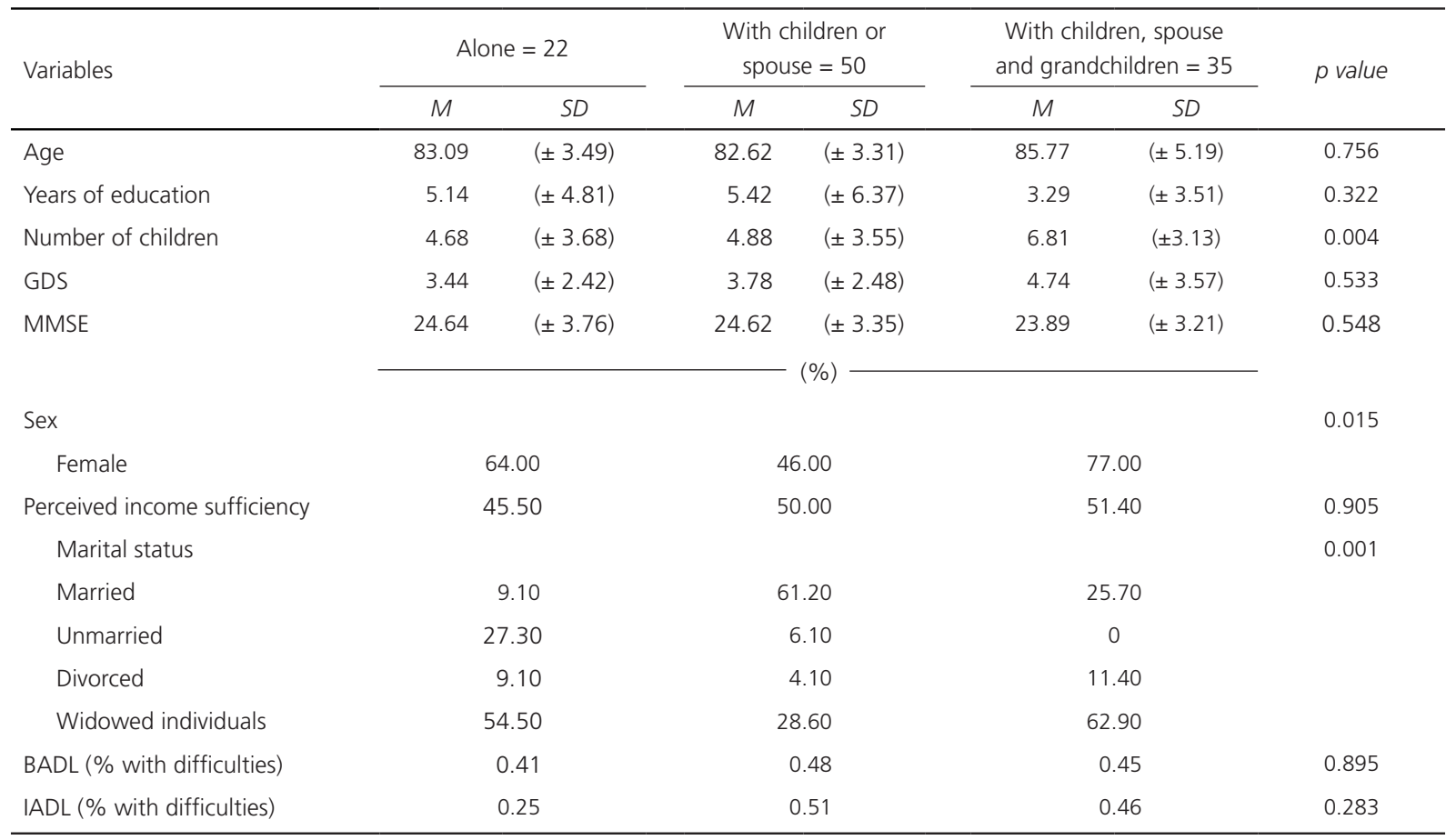

Note: BADL: Basic Activities of Daily Living; GDS: Geriatric Depression Scale; IADL: Instrumental Activities of Daily Living; M: Mean; MMSE: Mini Mental 
Table 2

Life Satisfaction Questionnaire according to the elderly individual household arrangement. Distrito Federal (Brazil), 2018

\begin{tabular}{|c|c|c|c|c|c|c|c|}
\hline \multirow[t]{2}{*}{ Variables } & \multicolumn{2}{|c|}{ Alone $=22$} & \multicolumn{2}{|c|}{$\begin{array}{l}\text { With children or } \\
\text { spouse }=50\end{array}$} & \multicolumn{2}{|c|}{$\begin{array}{l}\text { With children, spouse } \\
\text { and grandchildren = } 35\end{array}$} & \multirow[t]{2}{*}{$p$ value } \\
\hline & M & $S D$ & M & $S D$ & M & $S D$ & \\
\hline Life satisfaction today. & 2.69 & $( \pm 0.48)$ & 2.61 & $( \pm 0.55)$ & 2.46 & $( \pm 0.66)$ & 0.525 \\
\hline $\begin{array}{l}\text { Life satisfaction compared to other people of the } \\
\text { same age. }\end{array}$ & 2.56 & $( \pm 0.63)$ & 2.87 & $( \pm 0.34)$ & 2.54 & $( \pm 0.59)$ & 0.025 \\
\hline Satisfaction with your own memory. & 2.75 & $( \pm 0.45)$ & 2.37 & $( \pm 0.75)$ & 2.50 & $( \pm 0.66)$ & 0.215 \\
\hline $\begin{array}{l}\text { Satisfaction with the ability to perform everyday } \\
\text { tasks. }\end{array}$ & 2.69 & $( \pm 0.48)$ & 2.53 & $( \pm 0.65)$ & 2.38 & $( \pm 0.82)$ & 0.562 \\
\hline Satisfaction with family and friend relations. & 2.56 & $( \pm 0.81)$ & 2.86 & $( \pm 0.35)$ & 2.58 & $( \pm 0.72)$ & 0.228 \\
\hline Satisfaction with the environment in which you live. & 2.5 & $( \pm 0.63)$ & 2.45 & $( \pm 0.76)$ & 2.37 & $( \pm 0.82)$ & 0.950 \\
\hline Satisfaction with your access to health services. & 2.44 & $( \pm 0.81)$ & 2.39 & $( \pm 0.79)$ & 2.46 & $( \pm 0.78)$ & 0.467 \\
\hline $\begin{array}{l}\text { Satisfaction with the means of transportation } \\
\text { available to you. }\end{array}$ & 2.25 & $( \pm 0.86)$ & 2.38 & $( \pm 0.86)$ & 2.57 & $( \pm 0.73)$ & 0.756 \\
\hline Satisfaction with life in general (total sum). & 18.43 & $( \pm 4.61)$ & 19.30 & $( \pm 3.12)$ & 19.43 & $( \pm 3.69)$ & 0.869 \\
\hline
\end{tabular}

Note: M: Mean; SD: Standard Deviation.

Table 3

Social support questionnaire (ISEL) according to the elderly individuals' household arrangement. Distrito Federal (Brazil), 2018

\begin{tabular}{|c|c|c|c|c|c|c|c|}
\hline \multirow[t]{2}{*}{ Variables } & \multicolumn{2}{|c|}{ Alone $=22$} & \multicolumn{2}{|c|}{$\begin{array}{l}\text { With children or } \\
\text { spouse }=50\end{array}$} & \multicolumn{2}{|c|}{$\begin{array}{l}\text { With children, spouse and } \\
\text { grandchildren }=35\end{array}$} & \multirow[t]{2}{*}{$p$ value } \\
\hline & M & $S D$ & M & $S D$ & M & $S D$ & \\
\hline You have someone to talk to when you feel alone. & 3.13 & $( \pm 0.96)$ & 3.58 & $( \pm 0.76)$ & 3.13 & $( \pm 1.03)$ & 0.089 \\
\hline You meet and talk with friends and family regularly. & 3.37 & $( \pm 0.89)$ & 3.55 & $( \pm 0.80)$ & 3.62 & $( \pm 0.65)$ & 0.699 \\
\hline $\begin{array}{l}\text { You have someone who can help you with your } \\
\text { chores if you are sick. }\end{array}$ & 3.25 & $( \pm 1.34)$ & 3.45 & $( \pm 1.06)$ & 3.65 & $( \pm 0.71)$ & 0.808 \\
\hline $\begin{array}{l}\text { You can count on someone when you need a } \\
\text { suggestion on how to deal with a problem. }\end{array}$ & 3.33 & $( \pm 0.98)$ & 3.55 & $( \pm 0.95)$ & 3.58 & $( \pm 0.88)$ & 0.423 \\
\hline You have someone whose opinion you fully trust. & 3.67 & $( \pm 0.82)$ & 3.71 & $( \pm 0.77)$ & 3.79 & $( \pm 0.72)$ & 0.613 \\
\hline
\end{tabular}

Note: M: Mean; SD: Standard Deviation.

However, there was no relationship between the household arrangement, age, education, mood, the mean MSME score, and BADL- and IADL-related difficulties, which may be associated with two factors: (1) when selecting the cognitively healthy individuals ( $50 \%$ of the sample), the most dependent ones could have been excluded and this factor could have generated a selection bias; (2) it is a sample of elderly individuals with a high prevalence of functional difficulties (50\%) and less variability in relation to the sociodemographic variables investigated.

On these factors, other studies, such as the one by Rabelo and Neri (2015), used cluster analysis and identified the existence of three groups: elderly individuals who need instrumental help to perform everyday activities, with anxiety and dissatisfaction regarding family relations; elderly individuals who depend on others to perform activities of daily living, with anxiety and satisfaction with family relationships; and elderly individuals 
Table 4

Prevalence of Advanced Activities of Daily Living according to the household arrangement of cognitively healthy elderly individual. Distrito Federal (Brazil), 2018

\begin{tabular}{|c|c|c|c|c|}
\hline \multirow[t]{2}{*}{ Variables } & Alone $=22$ & $\begin{array}{l}\text { With children or } \\
\text { spouse }=50\end{array}$ & $\begin{array}{l}\text { With children, spouse and } \\
\text { grandchildren }=35\end{array}$ & \multirow[t]{2}{*}{ p value } \\
\hline & & $\%$ & 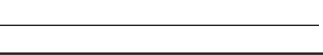 & \\
\hline You visit other people's homes & 77 & 78 & 69 & 0.591 \\
\hline You receive guests & 91 & 94 & 86 & 0.454 \\
\hline You go to the church or some other kind of religious temple & 82 & 76 & 63 & 0.247 \\
\hline You attend social meetings & 50 & 69 & 57 & 0.251 \\
\hline You participate in cultural events (exhibitions, films, cinema) & 14 & 35 & 14 & 0.045 \\
\hline You drive a car & 18 & 31 & 3 & 0.006 \\
\hline You make short, 1-day trips & 68 & 65 & 66 & 0.971 \\
\hline You make long trips & 68 & 65 & 66 & 0.490 \\
\hline You do volunteer work & 23 & 31 & 9 & 0.055 \\
\hline You do paid work activities & 9 & 14 & 6 & 0.439 \\
\hline You participate in boards and councils & 0 & 8 & 3 & 0.269 \\
\hline You go to University or take improvement courses & 0 & 4 & 6 & 0.541 \\
\hline Coexistence centers and groups for elderly individuals & 18 & 24 & 20 & 0.802 \\
\hline
\end{tabular}

who are fully independent and satisfied with their family relations. However, Rabelo \& Neri only analyzed elderly individuals who were 60 years-old or more, and used instruments that measured family functionality, which were not applied in this study. Satisfaction with family relationships is a factor that associates health and well-being in old age, and should be further investigated (Fuller-Iglesias et al., 2015).

Although other studies have related social support to the household arrangement (Alves et al., 2015; Borges \& Magalhães, 2011; Paúl, 2005; Rabelo \& Neri, 2015; Rosa et al., 2007) in this study there were no statistically significant associations between these variables. It was observed that the sample tended to have a high availability of self-perceived social, instrumental, affective, informative and social-emotional support. However, the tendency of the group with a uni- or bi-generational arrangement to have a greater availability of social-emotional support when compared to the others, may indicate that, in this aspect, the coexistence with the next generations favors these exchanges, performed by people who share common beliefs, stories and values.

Nevertheless, the data presented suggest that in old age, household arrangements can also be guided by intergenerational social exchanges, patterns of solidarity, altruism, and multigenerational care roles (Kenne \& Batson, 2010). In the first case, the changes would be based on economic reasons (Gazso, McDaniel, \& Waldron, 2016), while in the second case they would be associated with health care and disability needs related to health and functional disability (Kenne \& Batson, 2010).

According to data from the Pesquisa Nacional de Amostra por Domicílios (PNAD, National Household Sample Survey), in 2013 , there were families whose elderly individuals contributed with up to $54.6 \%$ of their income. However, it was found that older women started to head more households than in the past decades and that approximately two-thirds of the income came from Social Security (Camarano \& Kanso, 2016). In this case, the role of elderly individuals in multigenerational households may be linked to the role of the provider and the head of the family, evidencing social exchanges as a mechanism of economic protection and intergenerational survival (Gazso et al., 2016). In the present study, there was no association between the

8 household arrangement and the perception of income insufficiency, which may indicate that the economic 
contracts between generations may not be the determining factor for the household arrangement and advanced elderly individuals in the sample investigated.

On the other hand, multigenerational households can also be configured to support advanced elderly individuals, in addition to other variables such as marital status and gender. In this study, it was observed that women reported a higher prevalence of "uni-" and "tri-generational" household arrangements. Findings presented by Warner, Adams, and Anderson (2018) indicate that elderly individuals who reside alone reported more solitude, which is attenuated through social relations, functional limitations and the individual's sex. Brazilian elderly women are more likely to be widowed, and go through a longer period of pre-death functional disability (Camarano \& Kanso, 2016), indicating that the feminization of old age must be taken into long-term care.

With regard to other socio-demographic variables, the individual's marital status tends to be a great predictor of intergenerational co-residence, with uni- or bi-generational households mostly composed of married elderly individuals, while the tri-generations ones are mostly composed of elderly widowed individuals, supporting our findings (Kenne \& Batson, 2010). While marital status tends to moderate housing standards, on the other hand there are controversial findings on the relationship between widowhood in health indicators and the individual's well-being in old age (Burns, Browning, \& Kendig, 2015). With regard to the role of grandparents in the present study, it was not possible to determine whether they played any roles in the upbringing of their grandchildren, a fact that has been reported as having a negative impact on the health and well-being of elderly individuals (Kenne \& Batson, 2010). Data from North American studies indicate that $42 \%$ of the grandparents who corresponded with their grandchildren were also the legal guardians for those under the age of 18 , occupying the roles of providers and caregivers.

In summary, the data from the present study indicate that household arrangements in advanced old age are associated with family composition and some dimensions of life satisfaction and social involvement. However, it is important to note that the data refer to octogenarian and nonagenarian elderly individuals in an outpatient care clinic sample of the Federal District (Brazil), and that this population has a peculiar characteristic. It is a sample that originates mostly from other Brazilian states due to the foundation of the nation's capital, Brasilia. In this way, they have already established behavioral, emotional, and relational patterns permeated by diverse sociocultural characteristics. Previous studies have indicated that generational (Suanet \& Antonucci, 2017) or cultural patterns can moderate factors such as contact frequency, proximity, orientation and social network composition (Ajrouch, Fuller, Akiyama, \& Antonucci, 2018). Thus, the findings described are specific to the Federal District sample. It is necessary to elaborate more studies with Brazilian advanced elderly individuals, in order to verify if the household arrangements in advanced old age follow the same associations with socio-demographic variables, satisfaction with life, participation and social involvement. In summary, the findings highlight the need to deepen the way in which relationship patterns and generational exchanges are organized in the household arrangements in advanced old age.

\section{Contibutors}

M.C.G. OLIVEIRA and H. SALMAZO-SILVA conception and design of the research, analysis and interpretation of data. C.F. MORAES and L. GOMES collaborated with the review, and V.P. ALVES review and approval of the final version of the article.

\section{References}

Almeida, O. P., \& Almeida, S. A. (1999). Confiabilidade da versão brasileira da Escala de Depressão em Geriatria (GDS) versão reduzida. Arquivos de Neuro-Psiquiatria, 57, 421-426. http://dx.doi.org/10.1590/S0004-282X1999000300013 
Alves, M. R., Duarte, A. C. S., Meira, S. S., Nery, A. A., Silva, D. M., \& Vilela, A. B. A. (2015). Dinâmica das relações familiares intergeracionais na ótica de idosos residentes no Município de Jequié (Bahia), Brasil. Ciência \& Saúde Coletiva, 20(7), 2183-2191. http://dx.doi.org/10.1590/1413-81232015207.17972014

Ajrouch, K. J., Fuller, H. R., Akiyama, H., \& Antonucci, T. C. (2018). Convoys of social relations in cross-national context. The Gerontologist, 58(3), 488-499, http://dx.doi.org/10.1093/geront/gnw204

Borges, C. C., \& Magalhães, A. S. (2011). Laços intergeracionais no contexto contemporâneo. Estudos de Psicologia, 16(2), 171-177. http://dx.doi.org/10.1590/\$1413-294X2011000200008

Brucki, S. M. D., Nitrini, R., Caramelli, P., Bertolucci, P. H. F., \& Okamoto, I. H. (2003). Sugestões para o uso do miniexame do estado mental no Brasil. Arquivos de Neuropsiquiatria, 61, 777-781. http://dx.doi.org/10.1590/S0004-2 $82 \times 2003000500014$.

Burns, R., Browning, C., \& Kendig, H. (2015). Examining the 16-year trajectories of mental health and wellbeing through the transition into widowhood. International Psychogeriatrics, 27(12), 1979-1986. http://dx.doi.org/10.1017/ S1041610215000472

Cachioni, M., Delfino, L. L., Yassuda, M. S., Batistoni, S. S. T., Melo, R. C., \& Domingues, M. A. R. C. (2017). Bem-estar subjetivo e psicológico de idosos participantes de uma universidade aberta à terceira idade. Revista Brasileira de Geriatria e Gerontologia, 20(3), 340-352. http://dx.doi.org/10.1590/1981-22562017020.160179

Camarano, A. A., \& Kanso, S. (2016). Envelhecimento da população brasileira: uma contribuição demográfica. In E. V. Freitas \& L. Py, Tratado de Geriatria e Gerontologia (4a ed., pp.52-65) Rio de Janeiro: Guanabara Koogan.

Cohen S., Mermelstein R., Kamarck T., \& Hoberman H. (1995). Measuring the functional components of social support. In G. I. Sarason \& B. R. Sarason (Eds.), Social support: Theory, research and applications (pp.73-94). Leiden: Martinus Nijhoff.

D'Orsi, E., Xavier, A. J., \& Ramos, L. R. (2011). Work, social support and leisure protect the elderly from functional loss: EPIDOSO study. Revista de Saúde Pública, 45(4), 685-692. http://dx.doi.org/10.1590/S0034-89102011000400 007

Fuller-Iglesias, H. R., Webster, N. J., \& Antonucci, T. C. (2015). The complex nature of family support across the life span: Implications for psychological well-being. Developmental Psychology, 51(3), 277-288. http://dx.doi.org/10.1037/ a0038665

Gazso, A., McDaniel, S., \& Waldron, I. (2016). Networks of social support to manage poverty: More changeable than durable. Journal of Poverty, 20(4), 441-463. http://dx.doi.org/10.1080/10875549.2015.1112869

Keene, J. R., \& Batson, C. D. (2010). Under one roof: A review of research on intergenerational coresidence and multigenerational households in the United States. Sociology Compass, 4, 642-657. http://dx.doi.org/10.1111/j.1751-90 20.2010.00306.x

Lawton, M. P., \& Brody P. (1969). Assessment of older people: Self maintaining and instrumental activities of daily living. The Gerontologist, 9, 179-86. http://dx.doi.org/10.1093/geront/9.3_Part_1.179

Mantovani, E. P., Lucca, S. R., \& Neri, A. L. (2016). Associações entre significados de velhice e bem-estar subjetivo indicado por satisfação em idosos. Revista Brasileira de Geriatria e Gerontologia, 19(2), 203-222. http://dx.doi. org/10.1590/1809-98232016019.150041

Neri, A. L., Yassuda, M. S., Araújo L. F., Eulálio, M. C., Cabral, B. E., Siqueira, M. E. C., ... Moura, J. G. A. (2013). Metodologia e perfil sociodemográfico, cognitivo e de fragilidade de idosos comunitários de sete cidades brasileiras: estudo FIBRA. Cadernos Saúde Pública, 29(4), 778-792. http://dx.doi.org/10.1590/S0102-311X2013000400015

Neri, A. L., \& Vieira, L. A. M. (2013). Envolvimento social e suporte social percebido na velhice. Revista Brasileira de Geriatria e Gerontologia, 16(3), 419-432. http://dx.doi.org/10.1590/\$1809-98232013000300002

Neri A. L. (2002). Bienestar subjetivo en la vida adulta y en la vejez: Rumbo a una psicologia positiva en América Latina. Revista Latinoamericana de Psicologia, 43(1-2), 55-74.

Paúl, C. (2005). Envelhecimento activo e redes de suporte social. Sociologia, 15, 275-287.

Rabelo, D. F., \& Neri, A. L. (2015). Arranjos domiciliares, condições de saúde física e psicológica dos idosos e sua satisfação com as relações familiares. Revista Brasileira de Geriatria e Gerontologia, 18(3), 507-519. http://dx.doi. org/10.1590/1809-9823.2015.14120

Reuben, D. B., Laliberti, L., Hiris, J., \& Mor, V. (1990). A hierarchical exercise scale to measure function at the Advanced Activities of Daily Living (AADL) level. Journal of the American Geriatrics Society, 38(8), 855-861 http://doi. org/10.1111/j.1532-5415.1990.tb05699.x 
Rosa, T. E. C., Benício, M. H. D. -A., Alves, M. C. G. P., \& Lebrão, M. L. (2007). Aspectos estruturais e funcionais do apoio social de idosos do Município de São Paulo, Brasil. Caderno de Saúde Pública, 23(12), 2982-2992. http://dx.doi. org/10.1590/S0102-311X2007001200019

Suanet, B., \& Antonucci, T. C. (2017). Cohort differences in received social support in later life: The role of network type. The Journals of Gerontology: Series B, 72(4), 706-715. http://dx.doi.org/10.1093/geronb/gbw075

Teerawichitchainan, B., Pothisiri, \& Long, G. T. (2015). How do living arrangements and intergenerational support matter for psychological health of elderly parents? Evidence from Myanmar, Vietnam, and Thailand. Social Science and Medicine, 36(137), 106-116. http://dx.doi.org/10.1016/j.socscimed.2015.05.019

Warner, D. F., Adams, S. A., \& Anderson, R. K. (2018). The good, the bad, and the indifferent: Physical disability, social role configurations, and changes in loneliness among married and unmarried older adults. Journal of Aging and Health. http://dx.doi.org/10.1177/0898264318781129

Yesavage, J., Brink, T., Rose, T., Lun, O., Huang, V., Adey, N., \& Leirer, V. (1983). Development and validation of a geriatric depression scale: A preliminary report. Journal of Psychiatric Research, 17, 37-49. http://dx.doi.org/10.1016/00223956(82)90033-4

Received: July 17, 2018

Final version: Mach 15, 2019

Approved: April 2, 2019 